\section{Special Applications}

A white-emitting $(\mathrm{Zn}, \mathrm{Cd}) \mathrm{S}: \mathrm{Au}, \mathrm{Ag}$ phosphor was found unsuitable for commercial use in black-andwhite television tubes due to its rather low luminous efficiency. It has, however, proved effective in a special viewfinder tube, in which the screen is required to give a high degree of resolution $(32,33)$. The picture on the face plate of the tube is viewed through a magnifying lens in order to monitor a television camera. A conventional black-and-white television screen is not suitable for this application because the presence on it of both blue- and yellowemitting particles reduces its resolution.

A $\mathrm{ZnS}$ :Au phosphor is used also in a fluorescent indicator tube, in which the phosphor is excited by electrons accelerated by a low voltage of 30 to $60 \mathrm{~V}$, in contrast to the 10 to $30 \mathrm{kV}$ in television picture tubes (34). This tube displays alpha-numerical characters and is used in calculators and measuring instruments. Green-white-emitting zinc oxide was otherwise the only phosphor suitable for this purpose. Recently, tubes have been developed for use in multi-coloured displays on mass-produced audio appliances and inside automobiles. Gold-activated phosphors show the best performance as yellow-emitting substances for such devices when their electric conductivity is increased by mixing with non-luminescent indium oxide or zinc oxide.

\section{References}

1 S. Larach and A. E. Hardy, Proc. IEEE, 1973, 61, 915-926

2 Committee on Colorimetry, Optical Society of America, "The Science of Colour', Thomas Y. Crowell Co., 1953

3 A. E. Hardy, in 'Extended Abstr., Electrochen. Soc., Spring Meet., 1978', Abstract No. 323

4 C. B. Neal IEEE Trans., 1973, BTR-19, 149-162
5 S. Matsuura, T. Ito, Y Koga, M. Tamatani and Y. Ohtake, Toshiba Rev., 1978, 33, 515-518

6 T. Ito, in 'Extended Abstr., Electrochem. Soc., Spring Meet. 1978', Abstract No. 333

7 Y. Koga, T. Sumita, N. Inoue and S. Matsuura, U.S. Patent $4,151,442(1979)$

8 Y. Uehara and S. Ohmatoi, U.S. Patemt 4,140,940 (1979)

9 M. Oikawa and S. Matsuura, Japanese Prelim. Publ. 78-94281

10 R.R. Dodds and K. E. Landmesser, Japanese Prelim. Publ. 79-97591

11 T. Torii, Y. Nagashima, H.Kitamura and E. Mori, U.S Patem 3,922,233 (1975)

12 Y. Koga, W. Ichise and T. Sumita, Japanese Prelim. Publ. 78-15280

13 A. Suzuki and S. Shionoya, 7. Phys. Soc. Ipn., 1971, 31, 1455-1461 \& 1462-1468

14 S. Shionoya, in 'Luminescence of Inorganic Solids', edited by P. Goldberg, Academic Press, 1966, pp. 205-286

15 N. Kotera, S. Murakami and S. Eguchi, fapanese Prelim. Publ. $78-4784$ \& $78-14179$

16 S. Eguchi, N. Kotera and S. Murakami, fapanese Prelim. Publ. $78-14182 \& 78-14183$

17 Y. Nagashima, H. Kitamura, T. Ieda and E. Mori, Japanese Prelim. Publ. 76-4085

18 T. Ieda, N. Matsuhisa and S. Ohmatoi, Japanese Prelim. Publ. $78-142991$ \& 79-19483

19 F. A. Kröger, U.S. Patent 2,623,857 (1952) F. A. Kröger and J.A.M. Dikhoff, U.S. Patent 2,623,859 (1952)

20 N. Inoue and T. Kawamata, Japanese Prelim. Publ. 78-94282

21 M. Avinor, F. Electrochem. Soc., 1960, 107, 608-611

22 S. T. Henderson, P. W. Ranby and M. B. Halstead, F. Elecirochem. Soc., 1959, 106, 27-34

$23 \mathrm{H}$. W. Leverenz, 'An Introduction to Luminescence of Solids', Dover Publications, 1968

24 F. A. Kröger and J. A. M. Dikhoff, Physica, 1950, 16, 297-316

25 W. van Gool, Philips Res. Rep., 1961, Suppl. 3, pp. 1-119

26 T. Hoshina and H. Kawai, $\mathscr{f}$. Lumin., 1976, 12/13, 453-459

27 K. Kynev and R. Dafinova, Z. Phys. Chem. (Leipzig), 1977, 258, 394-396

28 K. Kynev and V. Kuk, Z. Naturforsch., 1979, 34A, 262-264

29 F. A. Kröger, A. Bril and J. A. M. Dikhorf, Philips Res, Rep. $1952,7,241-250$

30 Y. Koga, S. Matsuura and T. Wakatsuki, Gapanese Prelim. Publ. 79-57479

31 S. Matsuura and Tamatani, in 'Extended Abstr., Electrochem. Soc., Spring Meet., 1978', Abstract No. 334

32 A. Shigeya, Nat. Tech. Rep, 1979, 25, 197-205

$33 \mathrm{H}$. Tagawa and T. Sekiguchi, Gapanese Utility Model Publ. 75-195

34 A. Kagami, Y. Mitsumura, K. Narita and K. Kanda, in 'Abstr., 175th Meet. Phosphor Soc. Jpn.', Tokyo, 1979, pp. $7-13$

\title{
A Gold Mining Museum in Johannesburg
}

Over the last thirty years the centre of gravity of goid mining operations in South Africa has gradually moved away from the Johannesburg area, as new mines have been established elsewhere in the Witwatersrand basin. In the process the city, which has grown in less than a century from a scattered mining community to the major commercial and industrial centre of the country, has been losing many of its links with the past. Already some 60 mines that once flourished on the Reef are now only a memory.

All this made it imperative for a positive step to be taken to preserve the unique heritage of Johannesburg from the days when gold mining in South Africa was concentrated in its immediate neighbourhood.

The idea of creating a gold mining museum had been raised at various times over the years, but the donation by Rand Mines Properties of a section of Crown Mines - $10.5 \mathrm{hec}$ tares in area and containing the No. 14 Shaft, complete with headgear, winder house and other buildings - gave critical impetus to the project. Crown Mines was an ideal choice for a museum. It had been the world's foremost gold producer for years, and it is near the centre of Johannesburg - No. 14 Shaft being a mere $5.5 \mathrm{~km}$ from the City Hall. The decision to establish the museum at Crown Mines was taken by the gold mining members of the Chamber of Mines of South Africa in December 1978. Progress since then has been rapid and what once appeared a ghost mine has been transformed into a faithfully reconstructed and refurbished mine, typical of those in the area at the turn of the century. The complex was opened on June 5th, 1980.

The concept adopted by the South African gold mining industry is that the museum should be a living monument to its pioneers and also provide a major tourist and educational attraction. While the accent is on the early days of mining, there are also displays of modern equipment to give an insight into the latest techniques.

It is the aim of the Chamber, that the museum should become a showcase for the gold mining industry and a centre of technical and academic interest. 